\title{
Analysis and Review of Wife Inheritance and the Parents of the Deceased in the Religions with Holy Book
}

\author{
Ahmad Reza Behniafar ${ }^{1} \&$ Maryam Saadat Eftekhariyan ${ }^{2}$ \\ ${ }^{1}$ Department of Islamic Thoughts, Damghan Branch, Islamic Azad University, Damghan, Iran \\ 2 Department of Law, Damghan Branch, Islamic Azad University, Damghan, Iran \\ Correspondence: Ahmad Reza Behniafar, Department of Islamic Thoughts, Damghan Branch, Islamic Azad \\ University, Damghan, Iran. E-mail: behniafar@yahoo.com
}

Received: July 4, 2016 Accepted: August 10, 2016 Online Published: August 30, 2016

doi:10.5539/jpl.v9n7p270

URL: http://dx.doi.org/10.5539/jpl.v9n7p270

\begin{abstract}
To talk about human rights in the new and modern format and is one of the most important features of the contemporary era and in which, the rights of women is of particular importance. Elimination of legal discrimination due to gender, in different aspects of the life of human rights, with emphasis on women's rights forms the primary focus of all regional and international treaties and Declaration of women's rights. Defending financial rights of women including women's inheritance right is a critical argument.

With a careful study, we find that in various religions, wife inheritance is accepted and in divine religions (with the holy book). This issue has been respected and regarding form, there are similarities between the religions about the wife inheritance, However, apart from similarities, regarding essence, they have legislative differences. So in this seminar, the wife inheritance in divine religions is explained and analyzed, and comparative review of wife and parents estate of deceased in different religions is done so the problems in this regard can be obviated.
\end{abstract}

Keywords: inheritance, wife, divine religions, family rights, rights of wife

\section{Introduction}

Heritage in the history of nations has been influenced by the correct and corrupt habits and customs. In Islamic principles, inheritance issue is of great importance and in this regard, several verses from the holy book and didactic of Holy Qur'an and hundreds of decree and jurisprudential rule has been allocated to it. Without a doubt, inheritance is the most complex issue that has been discussed in detail in the legal and jurisprudential books under titles such as obstacles and conditions of inheritance.

Pay attention to heirs in matters of inheritance rights are important issues, and it is of utmost importance to respect women's rights. Elimination of legal discrimination due to gender, in different aspects of the life of human rights, with emphasis on women's rights forms the primary focus of all regional and international treaties and Declaration of women's rights and Defending financial rights of women including women's inheritance right is a critical argument. In all divine religions, there is no doubt that the rights of individuals, especially women's rights and their legacy issues are respected. This research tries to explain the status of wife inheritance rights and clarify the perspective of divine religions (religions with holy and sacred books) about it. Also analyzed a various aspect of the issue to take practical steps to resolve the existing problems in this field and as it is clear, in any of studies the concept is not stated explicitly. Always pointed as a marginal and stereotyped issue so as mentioned, in the seminar, legal and practical aspects of this topic are expressed reasonably. We intend to clarify the fundamental issue by doing research to eliminate the mentioned research gaps and thus respond the question of many students and researchers.

\section{Inheritance Status of Women in Ancient Civilizations}

In this season we will review the status of wife Inheritance in past centuries and great civilizations of the world and, we'll show that in the great civilizations of the world how many rights does the wife have and whether the wife could inherit in the past or not?

\section{The Status of Inheritance in Chinese Civilization}

As it can be inferred from historical documents, in the Age of Confucius (About 470-550 BC) in China, the 
father had the right to sell the women and children and also had the right to murder and kill their children. The greatest moral philosopher of China "Confucius" said: "The man, in any case, is dominant, and the woman is convicted." After the death of husband, the woman had no authority and autonomy and as a heritage, she should be under the authority of her husbands' family and male offspring to determine her fate according to their will and desire.

In Chinese poems we see "in the world, there is not something inferior and cheaper than a woman." (khamnhee 1991). It is clear that in such a community woman has no identity to specify rights for her (Savedji 1995). In China, as in other civilizations, the woman is deprived of inheritance, even a world-renowned historian. Will Durant writes: Chinese woman was condemned to kill herself for her loyalty after her husband's death, since the wife was forced to commit suicide after the death of her husband, there was no need of inheritance. In other words, Chinese woman wasn't alive after her husband, so the issue of inheritance is raised (Will Durant 1963).

\section{Inheritance Status of Women in Indian Civilization}

One of the most ancient heritages of human civilization can be seen in India and its neighboring countries. In India, Aryans patriarchy was dominant which was a past Hindu civilization heritage (Saleh Ali, 1970).

In ancient India based on a Codex (Manu), women were deprived of legacy and as well as Roman and Greek law, in India women were under the guardianship of man. In some ancient Indian tribes in the death of the husband, wife inherited like legacy or based on reprehensible and inhumane tradition of "sati" The woman was burned alive with the husband's corpse or strangled and put in the grave with her husband and believed that this is a sign of woman's loyalty. According to the rules of "Manu" three persons didn't have qualifications to possess the property, the wife of the deceased, the slave of deceased and daughter of the dead (Saleh Ali, 1970).

\section{Inheritance Status of Women in the Age of Ignorance}

Women in the era Arab ignorance had very abject and degraded state because the Uncultured Bedouins of that time, people was lagging and bigoted nation and among them there was the custom of slavery and class privilege and women were considered in rows of servant and slave. They hated and resented the girl and didn't find the girl as their child. One of the cruel traditions of them which all people knew, was that the innocent girls were buried alive as an escape from the shame and notoriety or fear of poverty and indigence that they were committed this crime, even the Quran has mentioned and has discouraged people from this. In the Quran, it is

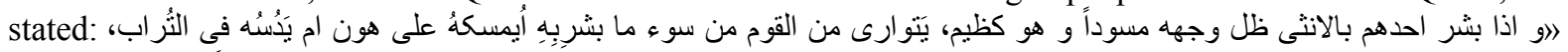

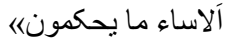

Verse Translation: If one of these Arabs were given the proper news of the birth of a girl, his face got black and was angry and concealed himself from the people. Since he was given the bad news that was and he started thinking and contemplating about whether to keep her and bear the shame and humiliation or hide them in the soil, that they will misjudge (Quran). It is evident that in such a society, not only for a woman there weren't economic rights, including the right to inheritance but also she inherited to another among the assets of the deceased (Mehrpour 2009).

As a general rule, we can say that in Arab ignorance regardless of deprivation of wife from inheritance and other social rights, basically Arabs didn't pay attention to women and even women were considered as the second gender.

\section{Heritage Status of Women in Ancient Persia}

Deceased doctor Amid, Musa in his pleadings of inheritance, stated: What is explicit and inferred from the documents and references related to the Sassanid time is that Persians' family was based on the foundation of patriarchy. So power and domination in the family have been in the control of grandparents and male children and relatives and after the death of the head of the family, property as a "Reliquiae" or heritage, was inherited by the eldest son and the eldest son was heir and successor of the father and ran customs and religious rituals and family affairs. Doctor Amid quoted from Professor Beloshe as saying In almost all rules of ancient nations which belong to Aryan race, the general principle that has dominated was that only the male children inherited and women were denied the right of inheritance (Dehkhoda, 1993).

Women in Sassanid civilization, the woman, wasn't a legal person, and the husband and father had broad powers of her property. The girl who married didn't inherit from his father or caretaker and for selecting husband she had no right, but if at the age of puberty, his father neglected from her conjugal act he was right in illegal marriage in this case she didn't inherit from his father (Nafisi 1967). 


\section{Compare the Inheritance of Men and Women in Religions (Other Than Islam)}

Judaism, Christianity, and Islam are popular divine religions, and since the Zoroastrian religion had the holy book, in the Shia perspective, thus it is among divine religions (Faheemi 2009). So at this section, we compare the inheritance of men and women in these divine religions.

\subsection{In Judaism}

In Jewish law, the general principle is based on the deprivation of women; especially wife from inheritance inferred decree of Torah is that when a son exists, the daughter doesn't inherit and if the deceased doesn't have a son, his inheritance reaches to his daughters. Verse 8 from chapter 27 numbers says, "And saying the children of Israel if someone dies and has no son, his property passes to his daughters (Jafari, 2001).

\subsection{In Christianity}

In Christianity, significant differences in the division of inheritance between men and women due to gender aren't observed. In this religion, girls and boys, brothers and sisters, parents, grandparents, aunts, and uncles, and male and female descendants, all gain an equal inheritance. Gender had no effect in determining their share of inheritance and both wife and husband, If they are the sole heir, so they have a similar interest. But if there are the other heirs such as offspring, under equal conditions, differences in the share of couples' inheritance can be seen (Katouzian 2008).

\subsection{In Zoroastrianism}

When a Zoroaster (both male and female) die without a will and His parents and wives and children be alive, his mother and father, if both of them are alive inherit $1 / 10$ and otherwise a person who is alive inherit $1 / 8$ share of inheritance, and the rest of the share is equal (Langroodi 2005). When the couple died in an accident together, the couple does not inherit from each other individually, and the heirs of each of them inherit separately and from his or her assets. When one of them dies, the division of inheritance between offspring will be different based on gender. Thus, compared to the legacy of their father, sons and daughters don't have equal shares, but the proportion of sons are twice as the share of and, compared to the legacy of their mother, the shares of sons and daughters will be equal (Shahidi 2012). At the time of the death of wife or husband that a spouse remained from him/her, without children of his/her own, and without a will, half of his/her property goes to the spouse, and the rest of it goes to parents, but if none of the parents are alive, all his assets will be transferred to his wife. If the deceased is a husband and has children, His wife's share of inheritance is $1 / 8$, and if the deceased is a wife and has children, her husband share is equal to the proportion of the deceased's son and daughter.

\section{Women Legacy Changes with the Advent of Islam}

At a time when all societies and civilizations of the world rejected the woman and had deprived her of inheritance and many other social rights. Islamic civilization started shining, and Quran was revealed to Prophet and honor the position and status of woman and donate social and civil rights to her. Also issued regulations about her inheritance which according to some historians, The Holy Quran in a section of inheritance grants several rights to a woman that are also preferred to the laws of the progressive nations of the world. Quran for women, including the wife, daughter, mother, sister, provides a share of inheritance in the deceased's legacy and condemned and sanctioned the woman being inherited and officially recognizing a share of inheritance for her as the man and considered independent, fixed and indisputable right of inheritance for her. Holy Quran in Sura Nisa verses 7 and 12 was given the right to inheritance independently for a woman and revived hope in the heart of women. We read in verse 7 of Sura Nisa:

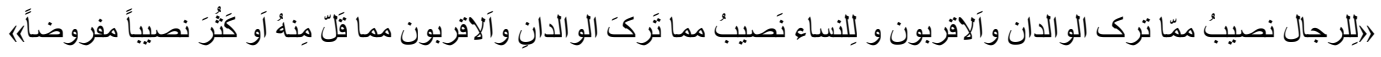

"For men, there is interest from what is leaving the parents and relatives and for a woman, there is interest from what parents and relatives leave for her whether little or much it is a Specified share."

In this verse, "woman" didn't point to "male" this is because it declared independence of women inheritance as men and this is what the world of that day could not accept it and was refreshing to them and when the above verse was revealed it was a surprise for Arabs ${ }^{18}$. After this promising verdict which for the first time considers women's inheritance independently, the next verses stated that inheritance of each class of women, including mothers, daughters, sisters, and wives. The Holy Quran in verse 12 of Nisa Sura in the statement of share of inheritance of wife says:

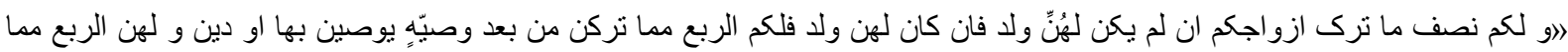

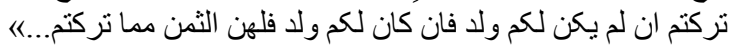

"Half of the legacy of your wife reach to you if you have no children so if you have a child one- fourth goes to 
you. After the address, the wills and debt of them, your wife gain a quarter of your share If you have no child, and if you have a child then one-eighth of inheritance is better for a woman."

Fourteen hundred years ago Islam established the law and in the same way that men have right in the results of their work from now on women are rightful for their works and activities. This verse has established a woman's right to inherit.

\section{The Base of Inheritance Belonging to the Wife in Islamic Jurisprudence and Civil Rights}

Since the rules of inheritance in Iranian law are based on Islamic law, in this article we try to examine the base and the reason of the wife's inheritance in Islamic jurisprudence and civil rights.

\subsection{The Inheritance Belonging to the Wife in Islamic Jurisprudence}

At the age of ignorance before Islam, Arab societies did not care to women. A woman in the tribe was considered shameful to the extent that Arabs buried alive their daughters as Allah says in the Holy Qur'an:

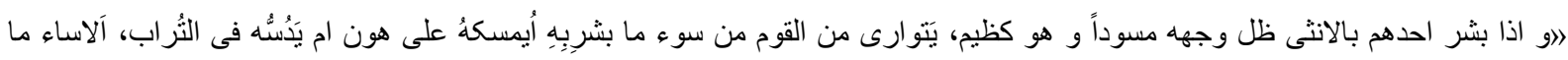
يحكمونهاء

If one of these Arabs were given the proper news of the birth of girls his face got black and was angry and concealed himself from the people and he started thinking and contemplating about whether bear the shame and humiliation and keep the child or hide them in the soil, know that they misjudge. "

The primary reason for exclusion of women from inheritance, in the days before Islam and Arab ignorance, was to prevent the transmission of family wealth to another family. According to old ideas, the role of the mother in the production of a child is weak, and mothers are just containers where male sperms are grown in theses containers hence believed that the son of men is one of his children and his family members and the daughter of a man aren't his children and his family members but they are one of the members of her husband's father family, and so if a girl inherited then her inheritance passed to her children and the wealth of a family moved to a different family

In such circumstances that ignorance and injustice had prevailed Saudi Arabia and other countries in the sixth century $\mathrm{AD}$, Islam emerged, and several various verses in regards to equal rights and status of women and men were revealed. Including the verse:

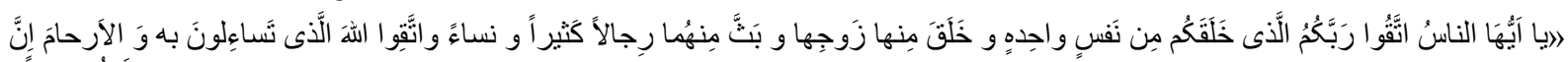

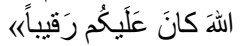

The translation of the verse: "Oh humankind! Fear your Lord, the God, who created you from a single person and that; he created the pair of him and from these two individuals very creation, men and women spread around the world and fear the God, who by the name of him you ask and have requested from each other and not neglect about relatives while God cares your actions."

In verse 13 of Surah Hogorat also says:

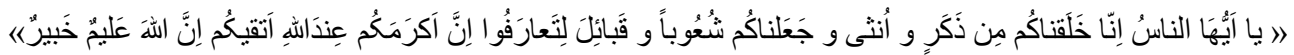

The translation of the verse: "Oh humankind! We created you from a male and a female; we divided you to tribes and families that you may know each other branches, but the greatest of you are the most virtuous and God is knowing and aware perfectly. "

In addition to the Quran, and the need to respect the dignity of women have been emphasized in the news and the instructions that Imams (PBUH) given. Imam Sadiq (PBUH) in this regard says: رجم الله عبداً احسنَ فيما بينهُ و بينَ زوجتهTranslation: "God have mercy on creation who has a good relationship with his wife".

Given the above, and compare the status of women in before Islam and after it, stressing the Qur'an and the Prophet (PBUH) to behave with justice and fairness to women and respect for their rights, it can be said that Inheritance to wife and to determine a certain amount of inheritance in Islam is based on justice and fairness. God's justice is one of the most prominent attributes and characteristics which have been emphasized in various verses of the Quran.

Like the verse:《واو السَّماءَ رَفَعَها وَ وَضَعَع الميزانَverse translation: "Lifted up the heavens and established justice,". In another place the Lord says:

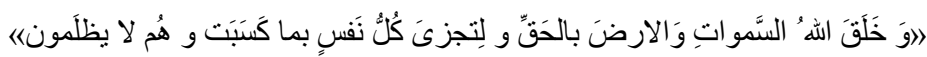

The translation of the verse: "God created the heavens and the earth with truth and justice (and in everything he has created, he has interest and purpose) and the end of each creation, without any oppression, get the results of 
any act that they have done."

The logic of Quran is justice and equality in for and against rights of one's, and if he considers any privilege for someone, in value perspective. It is because of the fear of God and not being a woman or a man and if this privilege is from Materialist aspect it meant to be an additional burden of responsibility that creation was placed on the shoulders of male or female by the condition.

This result because of God's justice to give her financial independence and has considered her the share of inheritance and knew her as one the heirs. However, the wife inheritance is less than a man and at first glance, this might be taken as an inequality between men and women.

But what is inferred by a more accurate reflection in issued sentences of the man and woman, is that issuing these orders is also based on God's justice. In other words, what is the meaning of justice is that in equal conditions and characteristics, no distinction between the rights of men and women in Islam jurisprudence can be seen and if in some provisions intended different rights for men or women, they are by the two distinct conditions regarding specification creation and social inequality and has caused The various responsibilities for each gender.

Therefore, we can say that it is based on justice and fairness that God sent down inheritance verses to his Prophet and in verse 12 of Sura Nisa regards the inheritance of wife he says:

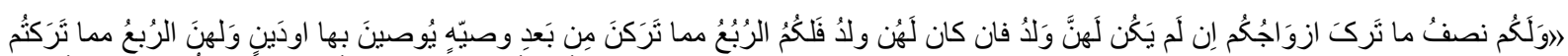

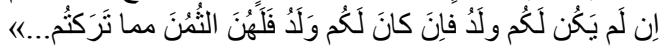

"Half of the legacy of your wife reach to you if you have no children so if you have a child one- fourth goes to you. After addressing the wills and debt of them, your wife gains a quarter of your share if you have no child, and if you have a child then one-eighth of inheritance is better for a woman."

\subsection{The Base of Inheritance Belonging to the Wife in Civil Rights}

Since according to the twelfth principle of the constitution "official religion of Iran is Islam and it builds on the Ja'fari Twelve Imams' school. "Therefore, according to the fourth article of that law "all laws and civil, criminal, financial, economic, administrative, cultural, military, political regulations must be based on Islamic criteria."

Since all of the provisions relating to inheritance adapted from Jurisprudence which relies on popular jurisprudential opinions. On the other hand during the history of the United Nations, inheritance was based on common social habits and at every age as far as to not disrupt the social order, moderation and fairness is observed. It does not specify to the laws of a particular nation, but all nations in the past periods of history haven't been strayed off this method (Saleh 1971).

Therefore, since all the rules and regulations of the Civil Code regards to wife inheritance is completely adapted of Jurisprudence and has followed most of the famous jurisprudents and as the basis of inheritance belonging to the wife in Islamic jurisprudence. According to Quran verses and hadiths (narrations) from the infallible Imams (BPUH), have been justice by inheritance belongs to the wife of civil rights also should by justice ruled.

Also in the passing articles relating to inheritance in civil law, contrary to the commitment seasons, foreign law is not considered, for instance in Chapter of obligations (commitment). Iranian legislator has taken the French Civil Code but in the regulations concerning the inheritance of it was quite obedient the jurisprudents and Shiite jurisprudence.

In Islamic jurisprudence, the need and fulfillment of justice are of particular importance. On the other hand, in the law also special consideration can be found for the concept of social justice. Especially in the countries that are seeking real(true) justice (such as Iran), special attention has been paid to justice, and its implementation in society and is emphasized as the most original and most important principle in its various aspects since all people of every class and category can benefit from the same rights. This case has been emphasized in our constitution.

In Article II of Iran's constitution, the justice of God has been noted as one of the general tenets of Islam, and it has been interpreted as one of the foundations of Islamic rule.

Accordingly, the legislator in Article 940 of the Civil Code stated that: "the couples that married permanently and aren't forbidden from inheritance, they inherit from each other". Also, it is based on respecting for more justice and fairness that legislators are trying to reform the wife inheritance issues from immovable property of husband and by the amendment of Articles 946 and 948 of the Civil Code. The wife who was deprived of inheriting land, was placed among the heirs of that property so that Article 946 of the Civil Code refers to: "wife inherits from all the assets of the husband and if the husband has a child the wife inherits one-eighth of movable 
property and one-eighth of the price of real estate including land and building and If the husband has no offspring, his wife share is a quarter of the property as mentioned above " and also Article 948 of the Civil Code provides that "If the heirs refuse to pay the price, a woman can ask for her right from the same property."

\section{Compare the Inheritance of Men and Women in Iranian Law}

In Iran's legal system which is based on the Quran and the Shiite jurisprudence Women along with men, regarding ancestry inherited but it was not the same as a man and based on the principle of the inheritance, her share of inheritance is half the inheritance of a man as the inheritance of daughter is half of the son, sister half of brother and woman half of husband (Articles 913, 907 and 920 of the Civil Code).

We can see three major differences in our provisions in the legal system between the inheritance of men and women:

1) If the deceased is a woman and has no offspring, her husband inherits half of her inheritance and if she has offspring her husband inherits one- fourth of her inheritance, but if the husband dies and has no offspring, his wife gain $1 / 4$ of his heritage, and if he has offspring, his wife gains $1 / 8$ of his heritage and generally and in any case the husband's share is two-fold.

2) If the wife has no other heir than the husband, then $1 / 2$ of her heritage and the rest is denied to husband, but if the husband dies and the wife is his unique heir, she will not gain more than $1 / 4$ of the heritage.

3) The husband inherits all the legacy of wife, and the wife inherits movable heritage of husband, but from immovable property such as building and land she just inherits only the price, Of course, before the reform of Civil Code she inherited only from buildings and trees.

\section{The Base for Partial Deprivation of Women's Inheritance than the Husband}

\subsection{First Opinion (View): Little Value and Authority of Women Compared to Men}

According to some authors which can be inferred from their writing, principally in Islam women have less value and authority compared to men and so that the credibility of the testimony of one man is equal to two women or her share of inheritance is half of the man, However, wherever financial valuing is considered the value of women and men are not equal.

The verse that has received considerable attention and by its interpretation, the superiority of men to women is proved is the verse of 《الرجال قوامون على النساءso that the Quran introduced the man as guardian, head of the woman, so the woman is in need of a guardian. As immature, stupid and insane is required guardian.

In response to a supporter of the superiority of men to women, it must be said that Islam condemns all forms of discrimination and undue privileges and Islam strongly opposes it. But the verses and narrations state that the criteria of the superiority of the male and female are virtue and value of women are as equal to men.

Like the following verse implies on this issue:

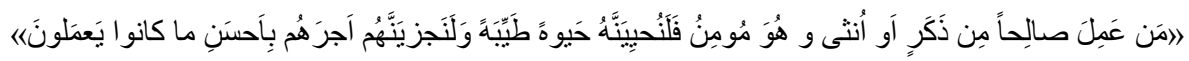

The translation of the verse, "Whoever, man or woman, does good work while he/she is a believer, certainly and we will bring him/her alive with true happiness in lives and certainly we will reward them better than what they had done." ${ }^{35}$.

Ayatollah Mousavi Boroujerdi also in the interpretation of the verse

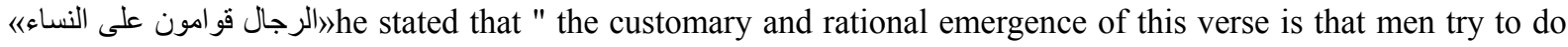
women works in matters of alimony and livelihood, and he believes. If there is an advantage or privilege in this verse, it is dedicated to a woman, not a man, because responsibility has been lifted from her shoulders.

\subsection{Second Opinion: Financial and Social Responsibility of Men Is More Than Women}

In Islamic law, a person who takes fiscal accountability and greater social burden, should have more right and win a larger share. The eldest offspring of the family has some of the father responsibility Such as the obligatory prayers which father couldn't do because of the illness leading to death and the eldest son must do them. So father exclusive property such as the Qur'an, ring, clothes, and personal items goes to the eldest son and doesn't divide among the other heirs. Regarding the inheritance of men and women since more financial responsibility has been laid on the man, so inheritance of man is more than woman.

Most experts believe that if the share of the inheritance of women is half of the men it doesn't mean that the value of a woman is lower than man, but It is because that man has a more effective role in economic life and family managing and the livelihood of the family is the man's responsibility. In fact, in Islamic legal system 
since financial accountability and social responsibility has been put on man's shoulder such as alimony of wife and children, and dowry payments, paying the cost of living off his wife, Participate in Jihad and family travel expenses and payment of alimony to the woman and child in those days, payment of blood money, paying the poor to other relatives (such as parents and sister) In some cases, so man's share is twice as wife.

The role of man in gaining and the accumulation of wealth is more than a woman, and often the father runs the family with the help and assistance of his male offspring, and what he gain is typical due to his and his male offspring toil. Equitable and fair distribution of income require that the male offspring inherits more than female since, also, to play more active role in the gaining wealth, male offspring requires more property, so the needs of both parties in the division of heritage are intended.

In the case of inheritance due to less legacy of women than men, there are several Hadiths and reports Including a hadith by Imam Sadiq (PBUH) that one of the people opposed to Islam asked him, why women despite the fact that they are weaker and more incapable than men but to inherit half of the men? Imam said:

》إنّ المر أه ليس عليها جهاد و لانفقه و لامعقله و انما ذلى على الرجال فلذالك جعل المر أه سهماً و للرجل سهمين《

It means that "the woman is not required to jihad, alimony and paying money to others while it is the responsibility of men, therefore, for women and men a fixed share of the contribution is placed.

In another hadith, Imam Reza (PBUH) was asked in this regard, Imam said, "The reason that women's inheritance is half of the men is that when women marry, something (dowry and alimony) are given to them, but men must pay something (dowry and alimony) therefore men inherit more ${ }^{41}$. Based on what has mentioned, we reach to this conclusion that the inheritance of men isn't more than women's inheritance, since whatever a man gains, he spends for his family and doesn't save anything for himself, but whatever the woman takes she will save for the future. Allama Tabatabai in Al-Mizan in this regard says: "Islamic theory about the distribution of wealth in the world is based on the Trinity. $1 / 3$ of that property is owned by women and $2 / 3$ is owned by men but in using these ratios are getting reverse. In the possession, the man gains twice of the woman, but in consumption, the woman takes double, because of the man's $2 / 3$ share, $1 / 3$ goes to a woman, but the woman spends her share for herself.

Finally, although the inheritance of women compared to men faced with minor or partial deprivations women have financial privilege such as the right of dowry, the right of housing, and right of alimony and child support that women are exempted from it, and men don't have these privileges.

\section{Conclusion}

The result of this study can be summed up in this way that in the divine religions section, in Zoroastrianism, men in benefit from the legacy of women have the same proportion of women, but women in utilizing the heritage of men inherit half of men's share and confront with partial deprivation. In Judaism the paternal relationship is the criteria to benefit from inheritance and relatives from the mother are deprived of inheritance. Among the maternal family members, the men were considered superior to women. Mother is entirely stripped of the heritage and wife faced with partial exclusion. In Christianity, significant differences in inheritance between men and women aren't observed.

In the well-known ancient civilizations section, Rome, Babylon, Persia, China and Japan, India and the Arabian Peninsula before Islam clearly were dominant. The total exclusion of women and sometimes human is that not being considered them. In the Iranian and Islamic law in regulating the classes of heritage, there are no differences between men and women and women are not faced with total deprivation. But women under the headings of the mother, daughter, wife, sister, grandmother, and aunt, on equal terms, face with partial denial of inheritance compared to male.

In the comparative and evaluating, and in fact concluding collections of the other views a comparison of the legacy of men and women once again had to be emphasized that being just or unjust of the legal regime of inheritance in each of these mentioned religions and civilizations should be assessed according to her financial rights and obligations set in the system.

So equality of women with men in the enjoyment of inheritance in Christianity along with his deprivation of dowry cannot be considered an advantage and total and partial deprivation of women from inheritance in Zoroastrianism and Judaism. If not accompanied by additional financial Privileges such as dowry and alimony with no doubt will be true oppression and discrimination as well as in the legal regime of inheritance in Islam. Although the woman is facing with partial deprivation of inheritance, because she was having financial privileges such as dowry and alimony, this exclusion shall not lead to injustice; It must be said that this legal regime provides the better position of moral and material interests of women. 
The general and total deprivation of women which can be seen in some major religions and ancient civilizations of humankind are not tenable and in any way, it is an anti-human phenomenon.

Finally, we should emphasize that In Islamic law, even by assuming the differences of male and female and accepting that the female share of the inheritance is half of the men are based on Quran ${ }^{59}$. Also, there are more ways for Women to take advantage, such as through the will, the father and husband can testate one-thirds of their heritage to goes to their daughter or their wife or wife during marriage. As the terms of the contract can provide some financial incentives for herself - as in a formal contract such circumstances suggested - and even some lawyers believe that legislators can also create a "legal presumption" to complete this issue: to declare that "if the woman is assumed to be the second or third class of heirs, It is believed that women can gain one-third of husbands' heritage, Unless the wills of the deceased or other documents proved something against it. "

They consider that in this way, the testament will not be imposed on husband and by any means, at his disposal (the will of private notes) he can express his opposition; because such a testament is not obligatory, but it is presumed. On the other hand, because after the publication of the law assumes that all people are aware, so silence of husband against this assumption will be interpreted as his Agreement; (Article 220 of Civil Code). Overview of wife inheritance among civilizations through history shows that not only inherit the ownership of the dead spouse was deprived but in some communities were considered the property of the heirs and the deceased was, but with the advent of Islam; the wife could inherit assets of her husband.

1) Overview of wife inheritance among civilizations through history shows that not only the wife of the deceased was deprived of property but also in some communities she was considered as the property and was in the hands of the heirs of the deceased, but with the advent of Islam, the wife could inherit assets of her husband.

2) Concerning the social status of the woman in the age of ignorance and compare her situation before and after the advent of Islam and emphasized of Quran verses, hadiths and sayings from infallible Imams (PBUH) based on the equality of women and men, as well as keeping the rights and respect the wife and implementing of justice in Islam's it seems that belonging inheritance to the wife in Islam is based on justice and fairness.

3) Wife with the general and specific eligibility and no barrier to inherit can use the assets as the wife of the deceased.

4) How a wife inherited is in a way that she inherited by all classes of heirs, and none of the heirs can't prevent her from inheriting the assets. In fact, the wife of the deceased can't prevent other heirs and relatives, and no heir can be prevented from inheriting her, but the wife has the supreme and under most heritage, assuming the wife with no offspring one-fourth and assuming the wife with offspring one-eighth of heritage goes to the wife.

5) legislator in Article 945, to fix and eliminate the problem of an ill and sick husband about the dangers of the heirs, in provisions of article 945 civil code has decreed for heirs of the deceased and in this matter. legislator didn't consider the rights of the wife as deserved because a woman who marries a sick man based on interest and altruism and the disease last few years and during this period sexually transmitted cannot be done, but the wife at the time does not hesitate of any assistance to her sick husband so prohibiting the wife from inheritance can't be inconsistent with justice and moral principles also, sometimes the wife is not aware her husband intention (which is damaging the heirs) and it seems that Article 945 requires the amending by the legislator.

6) jurisprudent verdict should be distinguished from the religious decree, Mixing the opinions of Islamic scholars with sources in Sharia has caused that someone thinks that any amendment or change in traditional Islamic jurisprudence is contrary to law. While it must be admitted that an important part of jurisprudence is based on rational deduction of ideas, so in the case that scholars disagree no rule oblige legislators to follow the popular opinion, in principle 167 of Constitution anticipated that the trial could, if there is not any law refers to the valid decree, the Non-famous decree may also be valid and pick it up with the judge.

As a result, it must be said, if the judge could follow the obsolete theoretical decree and not persuade from prestigious reputation and prefer substantial justice. Without a doubt, the legislator is also optional as the legislator in the amendment to Article 946 of the Civil Code previously followed famous jurists, this time, legislator follow Seyed Morteza, which is consistent with social interest and the requirements of time and place.

7) In the Quran which is the first and the most important source of Islamic law and is the criterion for the accuracy of other sources, there is not any clue and verse about inheritance deprivation of wife In verse 12 of Sura Nisa it is explicitly declared "women's heritage is aquarter of your inheritance, if you have no child and otherwise, one eight. 


\section{References}

Dehkhoda, A. (1993). Dictionaries (1st ed.). Tehran: Tehran University Press.

Durant, W. (1963). history of civilization (Vol. III), translation by Aryanpur doctor Amir Hossein, Iqbal Publications, Tehran, p. 1066.

Faheemi, F. (2009). Women and Financial Law (1st ed.). Tehran: Khorsandi Publication.

Geblei Khoi, Kh. (2010). Inheritance (2nd ed.). Tehran: SAMT Publication.

Heidari, A. (2009). Principles for deducting, translated by Zeraat, A, and the Masjed Saraby. Tehran: Publication of Islamic law.

Jafari,D. (2001). Place of contemplation and worship in Islamic teachings. Hozee Magazine, (49).

Katouzian. (2008). Lessons from preemption, wills, inheritance (10th ed.). Tehran: Mizan Publication.

Khamnhee, S. M. (1991). women's rights, Tak publication, Tehran, p. 26.

Langroodi, J. (2005). Inheritance (5th ed.). Tehran: Publication of Gange Danesh.

Mehrpour, H. (2009). wife inheritance in Islam and Iran's law (4th ed.). Tehran, Etelaat publication, p. 20.

Nafisi, S. (1967). the social history of Iran from the fall of the Sassanid to the extinction of the Umayyad, Printing Tehran, P. 42.

Pasha, S. A. (1970). legal history or the history of law. Tehran University Press, p. 62.

Savedji, M. (1995). women's rights in Islam, family, Tak Publications, Tehran, p. 30.

Shahidi, M. (2012). Inheritance (7th ed.). Tehran: Majd Publication.

The Holy Quran, Surah Nahl, verse 58 and 59.

\section{Copyrights}

Copyright for this articles retained by the author(s), with first publication rights granted to the journal.

This is an open-access article distributed under the terms and conditions of the Creative Commons Attribution license (http://creativecommons.org/licenses/by/4.0/). 